
with silicon. Horticultura Brasileira 36: 040-046. DOI - http://dx.doi.org/10.1590/S0102-053620180107

\title{
Productivity and quality of organic strawberries pre-harvest treated with silicon
}

\author{
Luana Marcele Munaretto ${ }^{1}$; Renato V Botelho ${ }^{1}$; Juliano Tadeu V Resende ${ }^{1}$; Kélin Schwarz ${ }^{1}$; Alessandro \\ Jefferson Sato ${ }^{2}$
}

${ }^{1}$ Universidade Estadual do Centro-Oeste (UNICENTRO), Guarapuava-PR, Brazil; luanamunaretto@yahoo.com.br; ${ }^{2}$ Universidade Federal do Paraná (UFPR), Palotina-PR, Brazil

\begin{abstract}
Mineral nutrients have important role in plant metabolism, acting on specific vital metabolic pathways for the cell. Among the nutrients, we highlight silicon ( $\mathrm{Si}$ ), for promoting growth, improving post-harvest quality and plant productivity, as well as being able to induce resistance to pest and disease. In this sense, this study aimed to evaluate the productivity and post-harvest quality of strawberry fruits cultivars Aromas and Albion cultivated in organic system with four doses of foliar applications of $\mathrm{SiO}_{2}$ in pre-harvest $(0,5$, $\left.10,15 \mathrm{~g} \mathrm{~L}^{-1}\right)$, and refrigerated storage ( 8 days under refrigeration and 1 day at room temperature). The valuated traits were: mass loss, fruit mass, productivity, fruit firmness, soluble solids, titratable acidity, total phenolics, total anthocyanins, ascorbic acid and soluble solids titratable acidity ratio. The cultivar Aromas presented higher productivity per area (33.05 $\left.\mathrm{tha}^{-1}\right)$, and more fruits per plot (479.42); however, higher average fruit mass was obtained in cultivar Albion (24.44 g), presenting better-quality fruits for fresh market. Soluble solids content, SS/TA ratio and ascorbic acid content were not influenced by silicon doses, however, refrigeration during 8 days and 1 day at room temperature provided reduction of fruit firmness, titratable acidity and, ascorbic acid content and increased soluble solids content and SS/TA ratio. Refrigeration attenuated significant reductions in anthocyanin content and, in addition, foliar silicon application promoted higher levels of anthocyanins in the fruits of both strawberry cultivars, increasing with the applied dose. The application of silicon was also efficient in maintaining fruit firmness of both cultivars.
\end{abstract}

Keywords: Fragaria $x$ ananassa, bioactive compounds, physicochemical characteristics, refrigeration.

\section{RESUMO}

Produtividade e qualidade de morangos orgânicos tratados em pré-colheita com óxido de silício

Os nutrientes minerais possuem funções importantes no metabolismo das plantas, atuando em rotas metabólicas específicas vitais para a célula. Entre os nutrientes, o silício (Si) merece destaque na agricultura por promover o crescimento, a melhora na qualidade pós-colheita e na produtividade das plantas, além de poder induzir a resistência ao ataque de pragas e doenças. Nesse sentido, o objetivo do trabalho foi avaliar a produtividade e qualidade pós-colheita de morangos das cvs. Aromas e Albion, cultivados em sistema orgânico de produção com aplicações foliares em pré-colheita de quatro doses de $\mathrm{SiO}_{2}\left(0,5,10,15 \mathrm{~g} \mathrm{~L}^{-1}\right)$, e armazenagem refrigerada (8 dias em refrigeração e mais 1 dia em temperatura ambiente). Foram avaliadas as características: perda de massa, massa de fruto, produtividade, firmeza, sólidos solúveis, acidez titulável, fenólicos totais, antocianinas totais, ácido ascórbico e a relação SS/AT. A cultivar Aromas apresentou maior produtividade por area $\left(33,05 \mathrm{tha}^{-1}\right)$, além de maior número de frutos por parcela $(479,4)$, porém a maior massa média de fruto foi obtida para a cultivar Albion $(24,4 \mathrm{~g})$, com melhor apresentação para a comercialização in natura. O teor de sólidos solúveis, relação $\mathrm{SS} / \mathrm{AT}$ e teor de ácido ascórbico não foram influenciados pelas doses de silício, porém o armazenamento sob refrigeração por 8 dias mais 1 dia em temperatura ambiente proporcionou redução da firmeza, da acidez titulável e do teor de ácido ascórbico e aumento no teor de sólidos solúveis e relação SS/AT. A refrigeração atenuou reduções significativas nos teores de antocianinas, além disso, a utilização de silício via foliar promoveu maiores teores de antocianinas nos frutos das duas cultivares de morangueiro, sendo crescente com o aumento da dose aplicada. A aplicação de silício foi também eficiente em manter a firmeza dos frutos de ambas as cultivares.

Palavras-chave: Fragaria $x$ ananassa, compostos bioativos, características físicas e químicas, refrigeração.

\section{Received on June 22, 2016; accepted on May 26, 2017}

$\mathrm{T}^{\mathrm{s}}$ he strawberry (Fragaria $\mathrm{x}$ ananassa) is a non-climacteric pseudofruit, which has a short post-harvest life due to the high percentage of water and high metabolism, demanding special care during harvest and post-harvest. The small fruits are quite susceptible to mechanical damage, dehydration, physiological degeneration, fungal rot and disturbances during storage, since this crop has no outer protective layer and low firmness when compared to other fruits (Chitarra \& Chitarra, 2005). In order to maintain acceptable characteristics, some techniques for decreasing senescence and increase the shelf life of the product are commonly used.

Some nutrients can contribute to the plant nutritional and structural complex, since they can influence on biochemical and/or physiological processes, being beneficial in fruit constitution, productivity and post- 
harvest qualities (Silva et al., 2013; Jana \& Jeong, 2014). One of the mineral elements which has aroused interest is silicon ( $\mathrm{Si}$ ) due to the benefits it can bring to some agricultural crops.

For the great majority of cultivated plants, including strawberry, Si can be considered as one beneficial element; studies about the effects of silicon on vegetables are scarce and the benefits of its use are related to structural functions and to plant defense (Wang \& Galleta, 1998). Among the advantages, we can highlight modifications this element propitiates in plant physiology, since it promotes an increase in leaf chlorophyll content in leaf tissue, interferes with plant architecture, providing more erect leaves, increasing solar radiation interception and avoiding excessive self-shadowing, delays senescence, increases tissue stiffness (Epstein \& Bloom, 2006), decreases transpiration rate and, provides higher photosynthetic efficiency, as it minimizes water loss (Korndörfer et al., 1999). Besides, this mineral can change the form of the compounds that are deposited in the tissues forming a silicon structure, which reduces water use and pest and phytopathogen attacks, since it interferes with penetration into the tissues (Reis et al., 2007). Also, another important piece of information on $\mathrm{Si}$ for crops is the improvement of the architecture of the plants which develop presenting more erect leaves facilitating light interception (Silva et al., 2013).

Although several studies show benefits of using silicon in agricultural crops (rice, sugar cane, sorghum, millet, oats, wheat, corn, kikuyu grass, bermuda grass) and some non-grass species (tomato, lettuce, cucumber, strawberry, melon) (Wang \& Galleta, 1998; Bae et al., 2010; Marodin et al., 2014), results about their effects on post-harvest quality of fruits and vegetables, mainly strawberry, are rare.

Silicon contributions are also positive, generating favorable results in the productivity and post-harvest quality of the fruits, presenting changes in anthocyanin concentration, soluble solids and titratable acidity, among others, in order to present a higher or lower commercial quality, such as in studies from Silva et al. (2013).

Considering that management in organic systems show restrictions on the use of some products during post-harvest storage and, products which are allowed to be used are still scarce in the market, the techniques which guarantee better quality products, without restrictions, should be applied. Thus, the aim of this study was to evaluate agronomic traits, related to post-harvest and the bioactive compounds of strawberry fruits from organic farming system after foliar application of silicon oxide and refrigerated storage.

\section{MATERIAL AND METHODS}

The experiment was conducted in the experimental field in Guarapuava, Paraná State, Brazil $\left(25^{\circ} 23^{\prime} 01^{\prime}\right.$ 'S, $51^{\circ} 29^{\prime} 37^{\prime \prime} \mathrm{W}$, altitude $1,120 \mathrm{~m}$ ). The soil is classified as typical dystrophic South Brazilian Oxisol clay texture (Embrapa, 2013). According to Köppen, the climate is mesothermic, wet subtropical, type $\mathrm{Cfb}$, with mild summers and winters, intense and frequent frosts, without dry season. Maximum average annual temperature is $23.5^{\circ} \mathrm{C}$ and minimum average annual temperature is $12.7^{\circ} \mathrm{C}$.

The area destined for the experiment has been submitted to practices allowed for the organic system according to Normative Instruction n. 46 of 2011 (Brazil, 2011), for a period exceeding seven years. When evaluating the soil chemical analysis, the authors obtained values of $\mathrm{pH}\left(\mathrm{CaCl}_{2}\right)=5.09 ; \mathrm{MO}\left(\mathrm{g} \mathrm{dm}^{-3}\right)$ $=51.18 ; \mathrm{P}$ Mehlich $\left(\mathrm{mg} \mathrm{dm}^{-3}\right)=8.70$; $\mathrm{K}=0.51 ; \mathrm{Ca}=3.93 ; \mathrm{Mg}=1.81 ; \mathrm{Al}=0.0$; $\mathrm{H}+\mathrm{Al}=4.89 ; \mathrm{SB}=6.25 ; \mathrm{CTC}=11.14$ to $\mathrm{pH}=7.0$, data expressed in $\mathrm{cmol}_{\mathrm{c}} \mathrm{dm}^{-3}$.

The studied cultivars were Albion and Aromas, from Chile, neutral photoperiod, which were selected according to the crown diameter (10 to $12 \mathrm{~mm}$ diameter) and root size (approximately $12 \mathrm{~cm}$ ).

The soil was previously corrected with calcitic limestone $\left(2 \mathrm{t} \mathrm{ha}^{-1}\right)$ and fertilized with tanned cattle manure $(20 \mathrm{t}$ $\left.\mathrm{ha}^{-1}\right)$. The seedlings were transplanted on July 9, 2012, in seedbeds covered with sawdust, 1.0-meter width, in spacing $30 \times 30 \mathrm{~cm}$ and dripping irrigated.
The experimental design was randomized blocks, in factorial scheme $4 \times 2 \times 2$ (doses of silicon $\mathrm{x}$ storage period $\mathrm{x}$ cultivars), with three replicates and experimental plot with 16 plants. The useful area of the plot consisted of 10 central plants.

The treatments consisted of biweekly sprays of aqueous solutions in the following concentrations of silicon oxide: $0,5,10$ and $15 \mathrm{~g} \mathrm{~L}^{-1}$. The authors used a pressurized costal sprayer based on $\mathrm{CO}_{2}$, equipped with a bar containing two empty conical nozzles, with constant pressure of 40 PSI, which allowed flow of $100 \mathrm{~L} \mathrm{ha}^{-1}$. Adhesive spreader was not added to the spray tank, however the weekly sprayings with neem oil, assisted silicon deposition rate on the leaf surface, since it has adhesive characteristics. As Si source, the authors used the commercial product AgriSi $\left(98 \%\right.$ of $\mathrm{SiO}_{2}$, Agrobiológica Soluções Naturais Ltda., Atibaia-SP). Si applications began when the first flowers appeared, on August 30, 2012 and extended to the end of the productive cycle, totalizing 12 applications.

Since it is an experiment on an organic system, the silicon oxide was applied interspersed with phytosanitary treatments every seven days after the first flowers. For phytosanitary treatments, the authors used the products chitosan (1\%), vegetable oil (1\%), garlic extract $(2 \%)$ or neem oil $(1 \%)$, totalizing 24 applications.

During the experiment, manual hoeings were done in order to control weeds according to the necessity. Fruits were harvested every three days, at maturity stage with $3 / 4$ fruit with intense red color.

After each harvest, the fruits of each experimental plot were weighed and quantified, in order to determine number of fruits, mass and productivity. Twenty fruits per experimental treatment were sampled, harvested at the same time, about 20 days, for being used in physicochemical evaluations. Half of this sample (10 fruits per plot) was taken to analyses in time zero. The other half (10 fruits per plot) was put in polypropylene bags, covered with PVC film $(0.017 \mathrm{~mm})$ and kept in chamber (BOD) at temperature of $1^{\circ} \mathrm{C}$ for 8 days 
and one more day at room temperature (approximately $19-25^{\circ} \mathrm{C}$ ), simulating marketing conditions. After this period, the fruits were submitted to analyses.

At time zero and $8+1$, the authors evaluated mass loss. The data were obtained using the difference of strawberry mass at time zero and time $8+1$ ratio; fruit firmness was determined using a digital penetrometer (SoilControl PDF-200) with a $2 \mathrm{~mm}$ diameter tip and penetration rate of $50 \%$, being the results expressed in Newton (N); soluble solids content (SS), determined in bench refractometer (Optech model RMT) with crushed pulp, and the values expresed in ${ }^{\circ}$ Brix; The total titratable acidity (AT) was determined by titration with $\mathrm{NaOH} 0,1 \mathrm{~mol} \mathrm{~L}^{-1}$ up to $\mathrm{pH} 8.2$ (IAL, 2005), showing results expressed in $\mathrm{mg}$ citric acid/100 g pulp; SS/AT ratio; ascorbic acid content (AA) was determined using the standard method of the Association of Official Analytical Chemists (AOAC) modified by Benassi \& Antunes (1988), and expressed in $\mathrm{mg}$ ascorbic acid/100 g pulp; total anthocyanins were determined using the method described by Giusti \& Wrosltad (2001), with adaptations for strawberry, expressed in $\mathrm{mg} / 100 \mathrm{~g}$; phenolic compounds obtained according to the methodology of Bucic-Kojic et al. (2007), by spectrophotometric method. Gallic acid was used as standard, considering the results expressed in $\mathrm{mg}$ gallic acid equivalent (GAE)/100 $\mathrm{g}$ of pulp. The analytical evaluations were performed in a completely randomized design and in triplicate for each plot.

The data were submitted to normality analysis (Shapiro-Wilk) and homogeneity of variances (Box-Cox) and, then, submitted to the variance analysis studying the interaction among factors, and when they were significant, the averages were compared using Tukey test $(\mathrm{p} \leq 0.05)$ and submitted to regression analysis for dose factor, using the software SISVAR 5.3 (Ferreira, 2010).

When interactions between cultivars and doses of Si were noticed, unfolding was used and for doses, the authors adopted regression equation, which better adjusted to the data, which was chosen based on the significance of the regression coefficients $(\mathrm{p} \leq 0.05)$ using F test, through SAS statistical program.

\section{RESULTS AND DISCUSSION}

The results for productivity, number and mass of fruits are presented in Table 1. For these variables, no interaction among factors was observed; only significant effect between cultivars was noticed. For mass loss, no statistical difference was verified. The analyses of variance of post-harvest traits of the evaluated strawberries did not show any interaction between cultivar and dose, except for fruit firmness. For soluble solids, pulp firmness, ascorbic acid and titratable acidity, the authors noticed significant effect of storage period under refrigeration.

For contents of total anthocyanins and titratable acidity, the authors noticed a significant effect of cultivar and, only anthocyanins differed statistically for the applied Si doses.

Cultivar Aromas was statistically superior to $\mathrm{cv}$. Albion in relation to productivity $\left(\mathrm{t} \mathrm{ha}^{-1}\right)$ and number of fruits. However, the same cultivar, despite producing more fruits, was inferior to Albion for average mass of fruits. These values were much higher than those found by Pádua et al. (2015), which found averages of 10.8 and 14.5 for cultivar Albion and 14.6 and 14.1 for cultivar Aromas.

Foliar silicon application did not provide higher productivity, number of fruits and average mass in this study. However, Silva et al. (2013) observed that doses of silicon applied to strawberry crop, both to the soil and the leaves, under protected environment, provided significant increase in fruit production. Thus, Filipczak et al. (2016)

Table 1. Number, average mass and fruit productivity of strawberry cultivars Albion and Aromas. Guarapuava, UNICENTRO, 2013.

\begin{tabular}{lccc}
\hline Cultivar & Number of fruits & Mass (g) & Productivity (t ha $\left.{ }^{-1}\right)$ \\
\hline Albion & $235.00 \mathrm{~b}^{1}$ & $24.44 \mathrm{a}$ & $23.04 \mathrm{~b}$ \\
Aromas & $479.42 \mathrm{a}$ & $17.02 \mathrm{~b}$ & $33.05 \mathrm{a}$ \\
\hline
\end{tabular}

${ }^{1}$ Means followed by the same letter in the column do not differ statistically by the Tukey test, $\mathrm{p} \leq 0.05$. also verified an increase in strawberry productivity after foliar Si application.

Non-significant result for $\mathrm{Si}$ application on productivity in this study can be related to large amount of organic matter applied to the soil, or even to the amount of organic matter present in the soil, considering that the cultivation area has been receiving large amounts of decomposing compounds of plant origin, that means, providing high $\mathrm{N}$ content in soil.

The increase of $\mathrm{N}$ content results in a decrease of the amount of $\mathrm{Si}$ accumulated in plants. The decrease of $\mathrm{Si}$ in vegetal tissues would be a result of dilution caused by nitrogen (Mauad et al., 2003). Thus, the increase of dry mass and fruit mass would be compromised. Another fact that could be responsible for the non-response of strawberry plants to Si doses, would be the condition that terrestrial plants, in general, contain $\mathrm{Si}$ in amounts comparable to the macronutrients, ranging from 0.1 to $10 \%$, being a major mineral constituent of some species (Ma \& Yamaji, 2006). Thus, the effects of Si applied via fertilization could be being masked, not reflecting positively on productivity and fruit mass. Yet, studies of Ribeiro et al. (1999), on coffee crop, show a decrease in root development due to the application of high level of calcium silicate to soil, which could reduce plant development and consequently compromise agronomic attributes.

One of the major problems faced by strawberry producers and consumers is the high perishability of fruits, and the use of refrigeration can minimize the post-harvest losses. In Figure 1A, the authors verified a reduction in pulp firmness after storage period under refrigeration of $7.77 \mathrm{~N}$ for $6.63 \mathrm{~N}$. The progressive loss of firmness or 
softening of the pulp occurs as a natural consequence of ripening.

The authors did not observe any differences between the cultivars in relation to refrigeration period of the fruits. Contrary to these results, Pelayo et al. (2003) observed during the storage of the fruits of cultivars Diamante and Selva, an increase in pulp firmness.

The applied silicon did not affect significantly fruit firmness under refrigeration. This result may be due to the fact that even being under low temperatures, sugar consumption occurred through cellular metabolism, through respiration, producing $\mathrm{CO}_{2}$, which stimulates ethylene synthesis, ripening regulator hormone (Steffens et al., 2007; Embrapa, 2013). In this sense, the enzymes involved in maturation, polygalacturonase and pectimethylesterase, had satisfactory conditions to act on the cell wall, specifically on pectates, decreasing fruit firmness (Chitarra \& Chitarra, 2005). Therefore, this fact explains firmness loss even for strawberry fruits which were under refrigeration in this study.

Cultivar Albion responded linearly to the increase of $\mathrm{Si}$ dose applied at pre-harvest for fruit firmness (Figure 1B). Cultivar Aromas, for the same trait, showed quadratic adjustment in the equation, with higher fruit firmness for the estimated dose of $8.1 \mathrm{~g} \mathrm{~L}^{-1}$ (Figure 1B). This result is extremely relevant, since it allows longer shelf life, besides showing higher resistance considering transport and storage. Strawberry is notably a perishable fruit which shows poor durability in post-harvest conservation and high susceptibility to handling damage. Marodin et al. (2014) observed improvement of the firmness of tomato fruits cultivar Kada Gigante due to the addition of Si to the solution, being, therefore, in conformity with what was observed in the present study. $\mathrm{Si}$ is part of the plant structure, its presence on the cell wall can increase the content of hemicellulose and lignin, increasing the stiffness of the cell wall (Kim et al., 2002). Moreover, silica can be deposited as a layer under the cuticle. This effect decreases transpiration, keeps the cell more turgid and, consequently, firmness of tissues, prolonging storage (Kim et al., 2002). This is due, mainly, to the fact that silicon is present in lumen and in cell wall and in intercellular spaces of the plants as amorphous silica (Ma \& Yamaji, 2006). Furthermore, in cellular epidermis, the silicon adheres to cellulose and may be present in stomata, in trichomes and in the elements of the vessels, providing more firmness to the

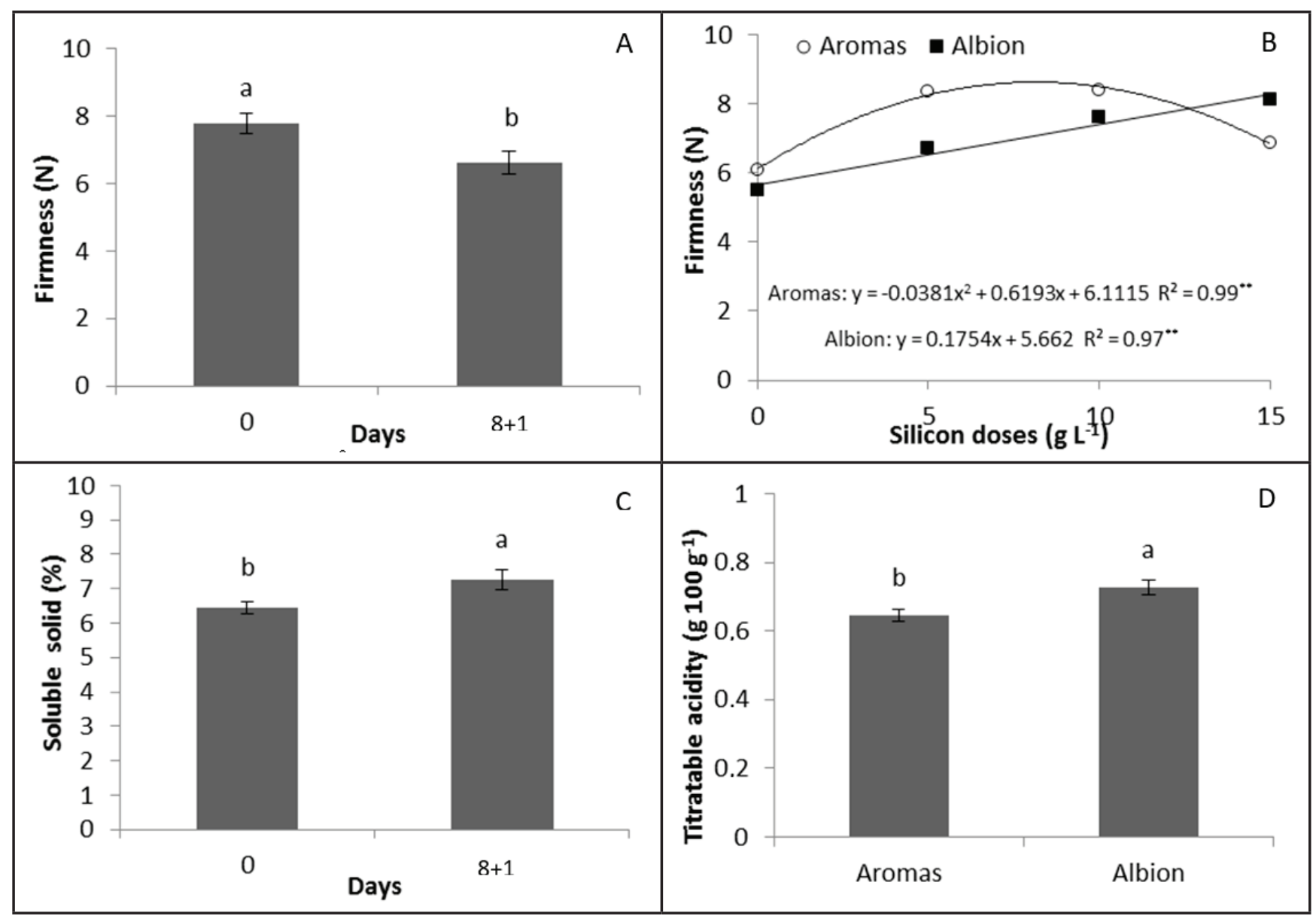

Figure 1.A) Fruit firmness of strawberry in relation to the refrigerated storage during 8 days +1 day unter room temperature B) Fruit firmness of strawberry cv. Albion and cv. Aromas in relation to the concentration of $\mathrm{SiO}_{2}\left(\mathrm{~g} \mathrm{~L}^{-1}\right)$, applied at pre-harvest; C) Average of soluble solids content of strawberry fruits cvs. Albion and Aromas in relation to the storage period; D) Titratable acidity of strawberry fruits considering Albion and Aromas cultivars. Guarapuava, UNICENTRO, 2013. 


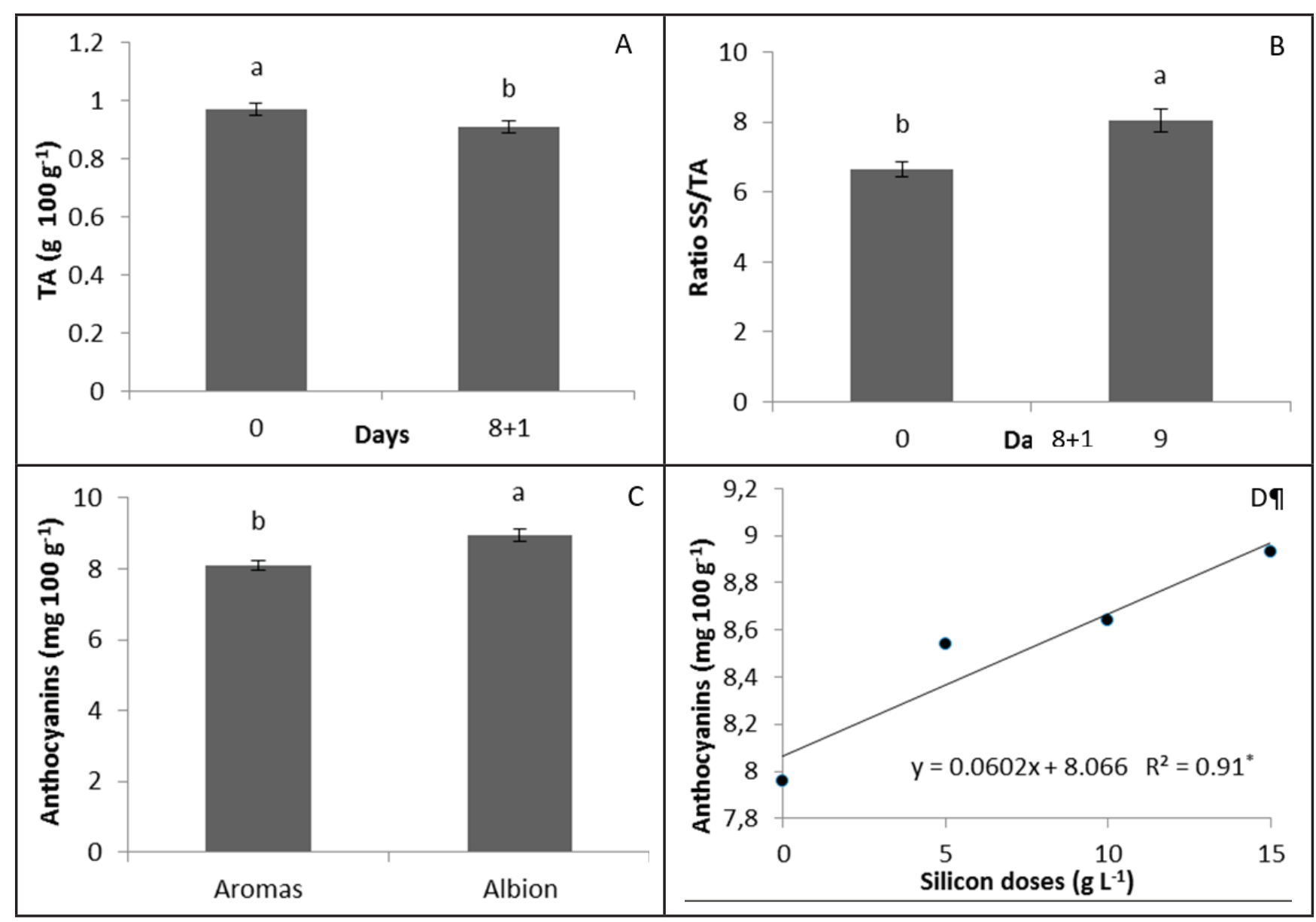

Figure 2. A) Titratable acidity of strawberry fruits cvs. Albion and Aromas in relation to storage period. B) SS/AT ratio in relation to storage period. C) Anthocyanins content of strawberry fruits of cultivars Albion and Aromas. D) Anthocyanins content of strawberry fruit in relation to the silicon doses applied to the leaves before harvest. Guarapuava, UNICENTRO, 2013.

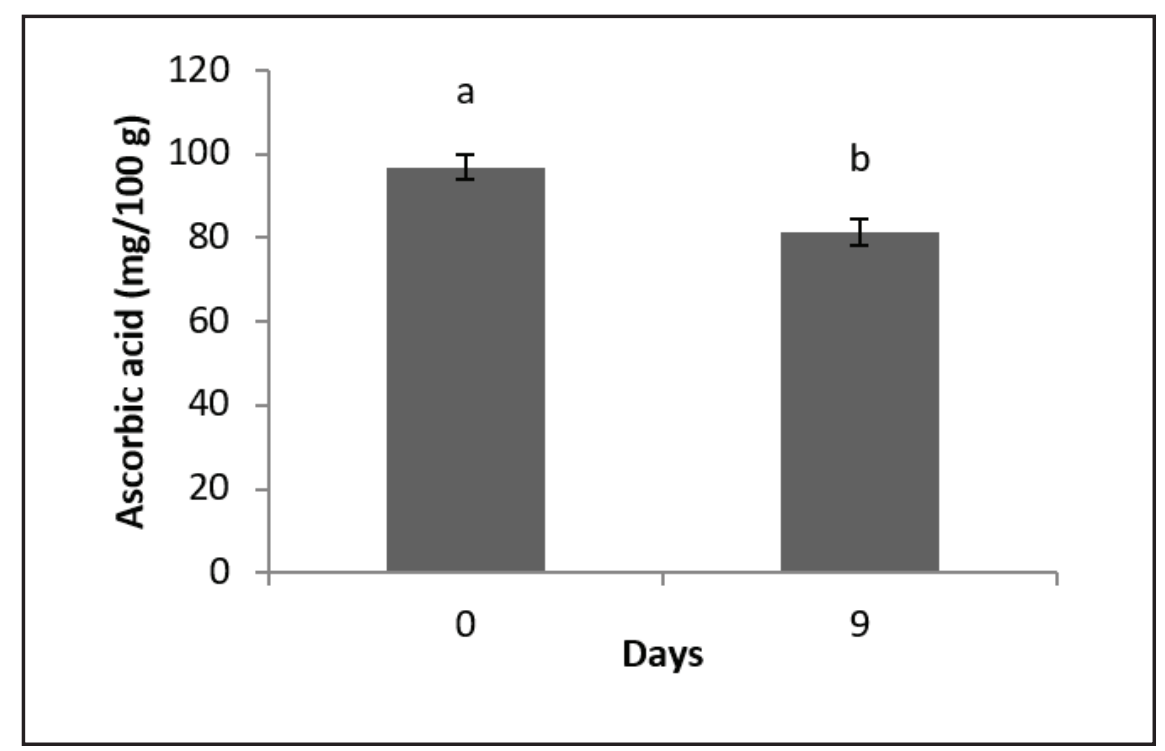

Figure 3. Average values of ascorbic acid content of strawberry fruit in relation to storage period. Guarapuava, UNICENTRO, 2013.

plant structures, including the fruit.

As expected, soluble solids contents (SS) increased significantly in relation to storage period under refrigeration, as expected (Figure 1C). This is due to the transformations of accumulated reserves during the formation and development of these solids in soluble sugars (Jeronimo
\& Kanesino, 2000). Silva et al. (2011), in their study, found similar variation of soluble solids contents, with increasing values from $7.5^{\circ} \mathrm{Brix}$ to $10.5^{\circ} \mathrm{Brix}$ during 6-day storage for strawberry fruits. Silva et al. (2013) also verified higher concentration of soluble solids, from $6^{\circ}$ Brix to $7^{\circ}$ Brix after storage of strawberries treated with silicon.

For titratable acidity (AT) the acceptable contents for consumers are from 0.5 to $1.87 \mathrm{~g}$ of citric acid $100 \mathrm{~g}$ pulp (Kader, 1991). The AT values in this study are within the range (Figure 1 ), that means, for cultivar Aromas 0.645 and Albion $0.727 \mathrm{~g}$ of citric $\mathrm{acid} / 100 \mathrm{~g}$ pulp. The difference observed was due to the cultivar, since according to Krolow \& Schwengber (2007) the cultivar Albion presents, normally, higher AT, when compared to cultivar Aromas. Carvalho et al. (2013) also obtained results, similar to the found in this study, when compared to the 
cultivars Albion and Aromas for AT.

The organic acids present in the fruits, in balance with the sugar level, represent an important quality attribute. Many of these acids are volatile, thus contributing to the aroma of the fruits (Kluge et al., 2002).

AT decreased due to storage period under refrigeration for both evaluated cultivars (Figure 2A), independently of the applied Si doses. These results were already expected since the organic acids tend to decrease during fruit ripening, since it is used as substrate in respiration and also the AT reduction is more pronounced when the fruits are stored, even under refrigeration (Françoso et al., 2008). Malgarim et al. (2006) also observed that strawberry cultivar Camarosa showed reduction in titratable acidity content during storage when compared to the control fruits, considering this value equal to 0.65 during harvest and $0.55 \mathrm{~g}$ of citric $\mathrm{acid} / 100 \mathrm{~g}$ of pulp on the ninth day. This difference is due, mainly, to metabolic effects on the cell, even after harvest.

$\mathrm{SS} / \mathrm{AT}$ ratio represents the balance between the contents of acids and sugars in fruits, conditioned by the balance between taste and aroma. Regarding this ratio, the authors noticed statistical difference only for storage period, in which the best ratio was found after storage (Figure 2B). These results corroborate the studies from Ávila et al. (2012), which state that, after the eighth day of storage, SS/AT ratio increased significantly, due to the increase of soluble solids concentration and decrease of titratable acidity. The SS/AT ratio found in this study, after storage (8.06), was slightly below to the one recommended for consumption since, according to Camargo et al. (2011), optimal indices for high quality fruits are around 8.75.

In relation to phenolic compounds, the authors noticed no significant differences for the evaluated traits, reaching average of $37.33 \mathrm{mg} / 100$ $\mathrm{g}$ of pulp. Phenolic compounds are important pigments for human health, as they present considerable ability to sequester free radicals, avoiding cell damage and preventing degenerative diseases (Meyers et al., 2003) and, for commercial purposes, these compounds are important because of the correlations between color and total quality.

For anthocyanins contents in strawberry pulp, the authors verified significant effect for cultivar factor, considering that Albion showed higher content $\left(8.94 \mathrm{mg} \mathrm{g}^{-1}\right)$ than cultivar Aromas (8.10 $\left.\mathrm{mg} \mathrm{g}^{-1}\right)$ (Figure 2C). These values are lower than the ones observed by Antunes et al. (2010), who observed contents of $38.01 \mathrm{mg} / 100 \mathrm{~g}$ of pulp in strawberry pulp of cultivar Camarosa and 22.6 and $29.2 \mathrm{mg} / 100 \mathrm{~g}$ of pulp for cultivars Oso Grande and Camino Real, respectively. Camargo et al. (2011) evaluated several cultivars under two growing systems (conventional and organic) and did not observe lower values than the ones obtained in this study. The different results may be due to maturity stage of fruits and variety; furthermore, anthocyanin forms may be subjected to interference from various factors, such as, temperature, $\mathrm{pH}$, and possible connections with other chemicals (Bordignon Junior et al., 2009).

The authors observed effect of $\mathrm{Si}$ doses, independent of the strawberry cultivar, for anthocyanin contents, it means, the contents increased according to the increase of foliar Si doses applied to the strawberry (Figure 2D). Silva et al. (2013) also verified that Si application provided an increase in anthocyanin concentration in relation to the values obtained in control treatment with the cultivar Milsei Tudla. Silicon is directly related to the formation of bioactive compounds, since it potentiates photosynthetic process (Gunes et al., 2007), contributes to higher production of Trioses - P, primary carbohydrate, that when in high concentration in plant, promotes activation of secondary metabolic pathways, responsible for the synthesis of these substances. In addition, silicon triggers a sequence of biochemical reactions in plants in the production of phenolic compounds, chitinases, peroxidases and lignin (Epstein, 1999). In relation to ascorbic acid content, the values found in this study (Figure 3) are higher than the average, showing that even after the loss during storage, the values were still higher than the ones reported in literature.

After 9 days of storage, the authors noticed a reduction in ascorbic acid levels when compared to the levels on the harvest day. This variation is related to the irreversible oxidation of L-ascorbic acid occurring mainly due to storage, which tends to decrease the ascorbic acid content (Rojas \& Gerschenson, 1997), which may compromise product quality (Chitarra \& Chitarra, 2005). The evaluated cultivars showed ascorbic acid contents lower than the ones found by Malgarim et al. (2006) $(54.47 \mathrm{mg} / 100 \mathrm{~g})$ and higher than the ones found by Rocha et al. (2008) (45 mg/100 g) for cultivar Aromas.

According to each cultivar, the authors could observe that the strawberry cultivar Aromas showed to be superior in productivity and number of fruits in relation to the cultivar Albion, which showed bigger fruits and with higher contents of soluble solids and anthocyanins, appropriate for in natura consumption. The two cultivars showed a decrease in titratable acidity when stored under refrigeration and, then, submitted to room temperature.

The application of mineral $(\mathrm{Si})$ showed to be effective when firmness was evaluated for both cultivars, being this trait of great importance since it allows longer distances to be traveled up to the market, without having the nutritional and visual qualities of strawberries damaged.

Storage of strawberries under refrigeration resulted in a qualitative loss in relation to ascorbic acid content, whereas $\mathrm{Si}$ applications promoted improvement in anthocyanins content. The contents of soluble solids and titratable acidity, SS/AT ratio and ascorbic acid content were not influenced by Si doses.

\section{REFERENCES}

ANTUNES, LEC; RISTOW, NC; KROLOW, ACR; CARPENEDO, S; REISSER JÚNIOR, C. 2010. Yield and quality of strawberry cultivars. Horticultura Brasileira 28: 222-226.

ÁVILA, FW; FAQUIN, V; LOBATO, AKS; BALIZA, DP; MARQUES, DJ; PASSOS, AMA; BASTOS, CEA; GUEDES, SEM. 
2012. Growth, phosphorus status, and nutritional aspect in common bean exposed to different soil phosphate levels and foliarapplied phosphorus forms. Scientific Research and Essays 7: 2195-2204.

BAE, MJ; PARK, YG; JEONG, BR. 2010. Effect of silicate fertilizer supplemented to the medium on rooting and subsequent growth of potted plants. Horticulture, Environment, and Biotechnology 51: 355-359.

BENASSI, MT; ANTUNES, AJ. 1988. A comparison of methaphosphoric and oxalic acids as extractant solutions for the determination of vitamin $\mathrm{C}$ in selected vegetables. Brazilian Archives of Biology and Technology 31: 507-513.

BORDIGNON JUNIOR, CL; FRANCESCATTO, V; NIENOW, AA; CALVETE, E; REGINATTO, FH. 2009. Influência do pH da solução extrativa no teor de antocianinas em frutos de morango. Ciência e Tecnologia de Alimentos 29: 183-188.

BRASIL. 2011. Instrução normativa $n^{\circ} 46$, de 06 de outubro de 2011. Lei $\mathrm{n}^{\circ} 10831$, de 23 de dezembro de 2003. Diário Oficial da República Federativa do Brasil, Poder Executivo, Brasília, DF, 06 Outubro. 2011. Seção 1, p. 8.a

BUCIC-KOJIC, A; PLANINIC, M; SRECKO, T; BILIC, M; VELIC, D. 2007. Study of solid-liquid extraction kinetics of total polyphenols from grape seeds. Journal of Food. Engineering 81: 236-242.

CAMARGO, LKP; RESENDE, JTV; TOMINAGA, TT; CAMARGO, CK; KURCHAIDT, SM; FIGUEIREDO, AS. 2011. Postharvest quality of strawberry fruits produced in organic and conventional systems. Horticultura Brasileira 29: 577-583.

CARVALHO, SF; FERREIRA, LV; PICOLOTTO, L; ANTUNES, LEC; CANTILLANO, RFF; AMARAL, PA; WEBER, D; MALGARIM, MB. 2013. Comportamento e qualidade de cultivares de morango (Fragaria $\mathrm{x}$ ananassa Duch.) na região de Pelotas-RS. Revista Iberoamericana de Tecnología Postcosecha 14: 176-180.

CHITARRA, MIF; CHITARRA, AB. 2005. Póscolheita de frutas e hortaliças: fisiologia e manuseio. 2 ed. Lavras: UFLA. 785p.

EMBRAPA. 2013. Sistema Brasileiro de Classificação de Solos. Brasília-DF. 353p.

EPSTEIN, E. 1999. Silicon in plants, facts vs. concepts. In: SILICON IN AGRICULTURE CONFERENCE, 1., 1999, Fort Lauderdale, Florida. Proceedings... Fort Lauderdale: [s.n.] p. 3.

EPSTEIN, E.; BLOOM, AJ. 2006. Nutrição mineral de plantas: princípios e perspectivas. Londrina: Editora Planta, 403p.

FERREIRA, DF. 2010. SISVAR - Sistema de análise de variância. Versão 5.3. Lavras: UFLA.

FILIPCZAK, J; SAS-PASZT, L; SZWONEK, E; LEWANDOWSKI, M; KOWALCZYK, W; POPIŃSKA-GIL, W. 2016. Response of two strawberry cultivars to the application of silicon. In: INTERNATIONAL CONFERENCE
MICROELEMENTS IN AGRICULTURE AND ENVIRONMENT, 13., 2016, Kudowa Zdroj, Poland. Proceedings... Kudowa Zdroj: [s.n.].

FRANÇOSO, IL; COUTO, MAL; CANNIATTIBRAZACA, SG. 2008. Alterações físicoquímicas em morangos (Fragaria ananassa Duch.) irradiados e armazenados. Ciência Tecnologia dos Alimentos 28: 614-619.

GIUSTI, MM; WROLSTAD, RE. 2001. Anthocyanins: characterization and measurement with uv-visible spectroscopy. In: WROLSTAD, RE (ed). Current protocols in food analytical chemistry. New York: John Wiley and Sons 2: 1-13.

GUNES, A; INAL, A; BAGCI, EG; COBAN, S; PILBEAM, DJ. 2007. Silicon mediates changes to some physiological and enzymatic parameters symptomatic for oxidative stress in spinach (Spinacia oleracea L) grown under B toxicity. Scientia Horticulturae 113: 113-119.

INSTITUTO ADOLFO LUTZ. 2005. Ministério da Saúde. Agência Nacional de Vigilância Sanitária. Métodos físico-químicos para análise de alimentos. Brasília: Ministério da Saúde.

JANA, S; JEONG, BR. 2014. Silicon: the most under-appreciated elements in horticultural crops. Trends in Horticultural Research 4: 1-19.

JERONIMO, RF; KANESINO, MAB. 2000. Efeito da associação de armazenamento sob refrigeração e atmosfera modificada na qualidade de mangas 'Palmer'. Revista Brasileira de Fruticultura 22: 237-243.

KADER, AA. 1991. Quality and its maintenance in relation to postharvest physiology of strawberry. In LUBY, A (ed). The strawberry into the $21^{s t}$ century. Oregon: Timber Press. p.145-152.

KIM, SG; KIM, W; PARK, EW; CHOI, D. 2002. Silicon-induced cell wall fortification of rice leaves: a possible cellular mechanism of enhanced host resistance to blast. Phytopathology 92: 1095-1103.

KLUGE, RA; NACHTIGAL, JC; FACHINELLO, JC; BILHALVA, AB. 2002. Fisiologia e manejo pós-colheita de frutas de clima temperado. Campinas: Livraria e Editora Rural. 2 ed. $214 \mathrm{p}$.

KORNDÖRFER, GH; COELHO, NM; SNYDER, GH; MIZUTANI, CT. 1999. Avaliação de métodos de extração de silício em solos cultivados com arroz de sequeiro. Revista Brasileira de Ciência do Solo 23: 101-106.

KROLOW, AC; SCHWENGBER, J. 2007. Avaliações físicas e químicas de morango cv. Aromas produzidos em sistema orgânico e convencional. Revista Brasileira de Agroecologia 732-1735.

MA, JF; YAMAJI, N. 2006. Silicon uptake and accumulation in higher plants. Trends in Plant Science 11: 342-397.

MALGARIM, MB; CANTILLANO, RFF; COUTINHO, EF. 2006. Sistemas e condições de colheita e armazenamento na qualidade de morangos cv. Camarosa. Revista Brasileira de Fruticultura 28: 185-189.
MARODIN, JC; RESENDE, JTV; MORALES, RGF; SILVA, MLS; GALVAO, AG; ZANIN, DS. 2014. Yield of tomato fruits in relation to silicon sources and rates. Horticultura Brasileira 32: 221-225.

MAUAD, M; GRASSI FILHO, H; CRUSCIOL, CAC; CORREAA, JC. 2003. Teores de silício no solo e na planta de arroz de terras altas com diferentes doses de adubação silicatada e nitrogenada. Revista Brasileira de Ciência do Solo 27: 867-873.

MEYERS, KJ; WATKINS, CB; PRITTS, MP; LIU, RH. 2003. Antioxidant and antiproliferative activities of strawberries. Journal of Agricultural and Food Chemistry 51: 6887-6892.

PÁDUA, JG; ROCHA, LCD; GONÇALVES, ED; ARAÚJO, TH; CARMO, EL; COSTA, R. 2015. Comportamento de cultivares de morangueiro em Maria da Fé e Inconfidentes, sul de Minas Gerais. Revista Agrogeoambiental 7: 69-79.

PELAYO, C; EBELER, SE; KADER, AA. 2003. Postharvest life and flavor quality of three strawberry cultivars kept at $5^{\circ} \mathrm{C}$ in air or air $+20 \mathrm{kPa} \mathrm{CO}_{2}$. Postharvest Biology and Technology 27: 171-183.

REIS, THP; GUIMARÃES, PTG; FIGUEIREDO, FC; POZZA, AAA; NOGUEIRA, FD; RODRIGUES, CR. 2007. O silício na nutrição e defesa de plantas. Belo Horizonte: EPAMIG.

RIBEIRO, AC; GUIMARAES, PTG; ALVAREZ, VH. 1999. Recomendação para o uso de corretivos e fertilizantes em Minas Gerais: $5^{\text {a }}$ aproximação. Viçosa: Comissão de Fertilidade de Solo do Estado de Minas Gerais. 359p.

ROCHA, DA; ABREU, CMP; CORRÊA, AD; SANTOS, CD; FONSECA, EWN. 2008. Análise comparativa de nutrientes funcionais em morangos de diferentes cultivares da região de Lavras-MG. Revista Brasileira de Fruticultura 30: 1124-1128.

ROJAS, AM; GERSCHENSON, LN. 1997. Ascorbic acid destruction in sweet aqueous model systems. LWT Food Science and Technology 30: 567- 572.

SILVA, MLS; RESENDE, JTV; TREVISAN, AR; FIGUEIREDO, AST; SCHWARZ, K. 2013. Influência do silício na produção e na qualidade de frutos do morangueiro, Semina: Ciências Agrárias 34: 3411-3424.

SILVA, PA; ABREU, CMP; QUEIROZ, ER; CORREA, AD; SANTOS, CD. 2011. Avaliação da qualidade de Morangos OsoGrande submetidos ao 1-metilciclopropeno. Revista Brasileira de Armazenamento 36: 13-21.

STEFFENS, CA; BRACKMANN, A; PINTO, JAV; EISERMANN, AC. 2007. Taxa respiratória de frutas de clima temperado. Pesquisa Agropecuária Brasileira 42: 313321.

WANG, SY; GALLETA, GJ. 1998. Foliar application of potassium silicate induces metabolic changes in strawberry plants. Journal of Plant Nutrition 21: 157-167. 